\title{
Kewirausahaan Sosial: Studi Kasus PT Kampung Kearifan Indonesia (Javara Indigenious) dan Remaja Mandiri Community (RMC)
}

\author{
Maria Dafrosa Naru \\ Fakultas Bisnis dan Ekonomika, Universitas Surabaya, Surabaya, Indonesia \\ faninaru91@gmail.com
}

\begin{abstract}
This article seeks to understand the principle of social enterprises by analyzing the two case studies in Indonesia with phenomenological approach. This study adopts qualitative approach by exploring two organizations, which aim to promote sustainable farming industry. The findings address three research questions, including how the social enterprises set their social mission, how they develop product innovation, how governance is in their organization by promoting fair trade. This article extends the discussion for the emerging concept of social enterprise by highlighting the social mission and social innovation.

Keywords: Social entrepreneurship, social mission, product innovation, governance, fair business.
\end{abstract}

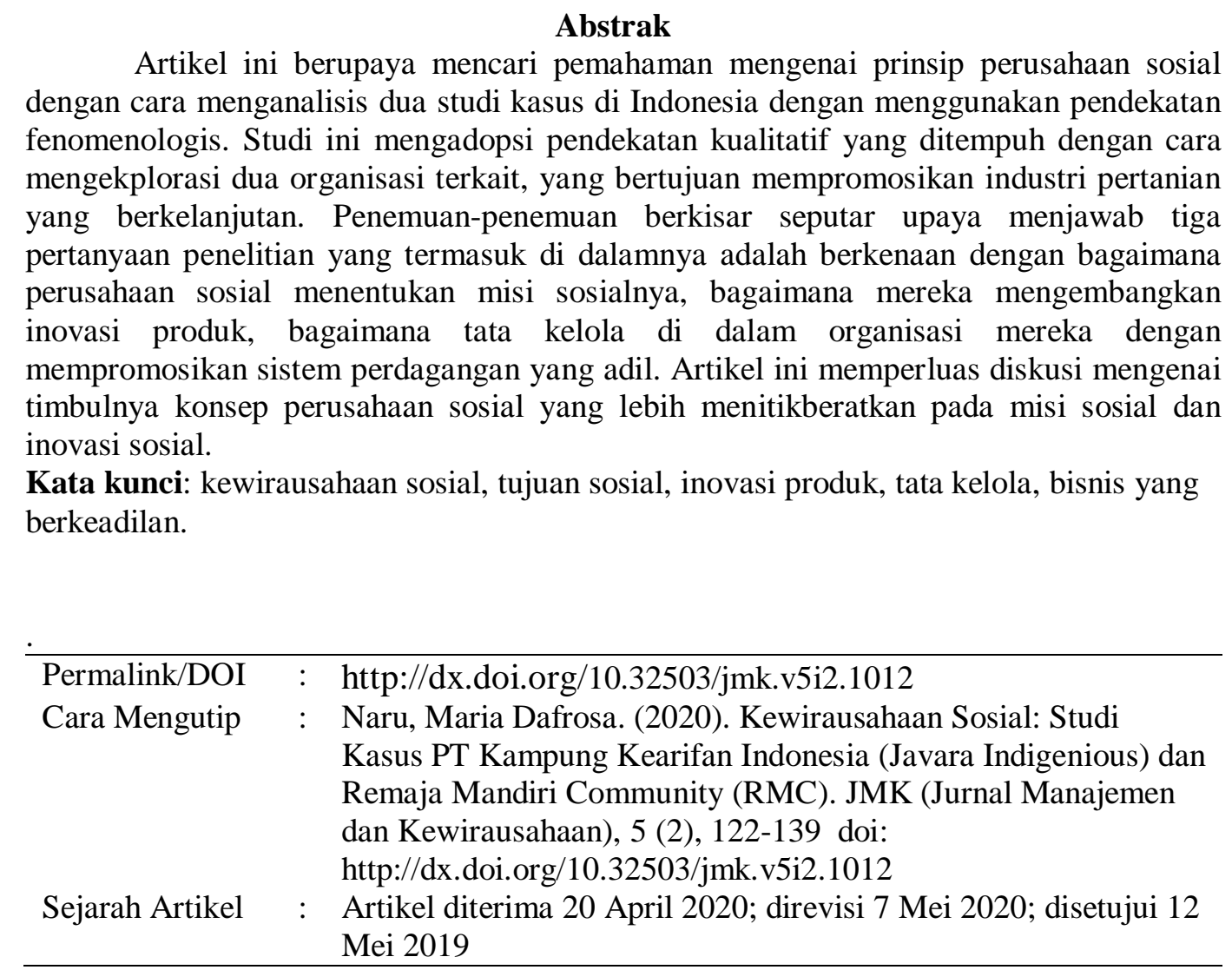

Alamat korespondensi :

Jl. Tenggilis Mejoyo, Kali Rungkut

Universitas Surabaya

Surabaya, Jawa Timur 


\section{Pendahuluan}

Permasalahan dalam hidup ini sangat kompleks diantaranya adalah perubahan iklim, bencana ekologis dan konservasi energi (Bostein, 2007 dalam Kickul dan Lyons, 2012). Masalah-masalah di atas telah berusaha dicari solusinya dari masa kemasa. Apalagi masalah yang terkait dengan lapangan kerja. Pemerintah dan masyarakat telah berusaha menanggulanginya. Namun tingkat pengangguran masih sangat tinggi, khususnya dikalangan anak-anak muda. Disaat-saat genting seperti inilah PT. Kampung Kearifan Indonesia (Javara Indigenious) dan Remaja Mandiri Community (RMC) muncul sebagai salah satu jawaban terhadap masalah-masalah di atas khususnya yang terkait dengan para petani. Dari pandangan peneliti 2 organisasi ini adalah yang paling berhasil secara konsisten membantu masyarakat petani, di pulau Jawa (Javara Indigenious) dan pulau Flores (RMC).

Proses pembelajaran dalam praktik kewirausahaan merupakan topik penting dalam studi kewirausahaan selama dua dekade terakhir. Pada tahun 2005, sebuah jurnal bereputasi bernama Entrepreneurship Theory and Practice menerbitkan topik khusus, yang menggambarkan pembelajaran sebagai momen penting dalam perkembangan kewirausahaan (Harrison dan Leitch, 2005). Sejak saat itu, semakin banyak artikel yang membahas aspek sosial pembelajaran, dan implikasinya terhadap pendidikan kewirausahaan (Yunxia, Rooney, \& Phillips, 2016). Pemikiran tentang pembelajaran dalam kewirausahaan telah berkembang pesat dan berfokus pada beberapa masalah seperti tujuan sosial dan sifat pembelajaran (Karatas-Ozkan, 2011), hubungan antara pembelajaran individu dan organisasi (Stinchfield, Nelson, \& Wood, 2012), dan implikasi dari pembelajaran perwakilan pada proses (Karataş-Özkan, 2011).

Perspektif teoretis mengenai kewirausahaan juga telah bergeser untuk lebih fokus pada implikasi hubungan sosial dan praktik kewirausahaan. Berbagai pertimbangan muncul tentang bagaimana teori berbasis praktik dapat menginformasikan dan menjelaskan pemahaman kita. Sebagai contoh, Jones dan Holt (2008) menggunakan teori aktivitas untuk mengkaji cara-cara di mana usaha wirausaha berubah selama tahun-tahun awal operasi mereka, dan menghubungkan pengalaman individu dengan pembelajaran organisasi (Jones \& Holt, 2008). Selain itu, pergeseran juga terjadi mengenai pentingnya belajar mengelola, bukan hanya materi, tetapi aspek simbolis dari usaha wirausaha sebagai pengusaha belajar bagaimana mengelola hubungan antar pemangku kepentingan (Clarke, 2011).

\begin{tabular}{lrr}
\multicolumn{2}{c}{ Perdebatan dalam kajian } \\
mengenai kewirausahaan juga \\
memberikan kesempatan untuk
\end{tabular}
mengeksplorasi aspek-aspek emosional pembelajaran (Cardon, Wincent, Singh, \& Drnovsek, 2009). Pergeseran ke studi yang berorientasi pada praktik mendorong para peneliti lebih memperhatikan proses seharihari yang biasa-biasa saja berdasarkan pegalaman para pengusaha yang memiliki pengaruh mendasar pada proses pembelajaran individu, kolektif, dan kebijakan (Anderson \& Thorpe, 2004). Selain itu, masih ada kekurangan kajian studi empiris yang solid sehingga memerlukan kajian 
pada konseptualisasi pembelajaran kewirausahaan dan dinamika praktik (Wang \& Chugh, 2014).

Artikel ini bertujuan untuk mengidentifikasi fenomena tentang bagaimana sebuah organisasi mengadopsi model bisnis kewirausahaan sosial. Untuk menjawab pertanyaan tersebut, studi ini mengembangkan upaya menjawab tiga pertanyaan penelitian yang termasuk di dalamnya adalah berkenaan dengan bagaimana perusahaan sosial menentukan misi sosialnya, bagaimana mereka mengembangkan inovasi produk, bagaimana tata kelola di dalam organisasi mereka dengan mempromosikan sistem perdagangan yang adil. Hal tersebut dikarenakan adanya kesulitan untuk mengidentifikasi populasi bagi perusahaan yang mengadopsi model kewirausahaan sosial, penelitian ini melakukan kajian berupa studi kasus dengan pendekatan fenomenologis

\section{Tinjauan Pustaka}

\section{Kewirausahaan Sosial}

Kewirausahaan

sosial

merupakan sebuah entitas dari subdivisi dalam sektor ketiga yang untuk mengatasi masalah sosial untuk standar kemanusiaan dan perawatan dengan melibatkan aktor ekonomi dan teknologi yang memungkinkan diterapkan untuk menciptakan model keuangan yang berkelanjutan (Borzaga \& Defourny, 2004) (Phillips, Lee, Ghobadian, O'Regan, \& James, 2015). Praktik wirausaha sosial terkait dengan inisiatif sosial untuk mengatasi masalah sosial dengan mengadopsi pendekatan bisnis (Defourny \& Nyssens, 2017). Beberapa penelitian sebelumnya berusaha mengidentifikasi beberapa elemen dalam kewirausahaan dengan mengidentifikasi keterlibatan pemangku kepentingan (Bidet \& Defourny, 2019), dampak sosial (Kelly, Steiner, Mazzei, \& Baker, 2019), perubahan misi (Mersland, Nyarko, \& Szafarz, 2019), dan kinerja atau manfaat yang dihasilkan (Battarai, Kwong, \& Tasavori, 2019).

Suatu organisasi dianggap sebagai perusahaan sosial jika mereka mengelola (1) produksi barang dan jasa permanen, (2) tingkat otonomi yang relatif tinggi, (3) tingkat risiko ekonomi yang signifikan, (4) dan pekerja professional (Borzaga \& Defourny, 2004). Mempertimbangkan definisi yang disarankan oleh Departemen Perdagangan dan Industri di Inggris, perusahaan sosial adalah organisasi bisnis dengan tujuan sosial utama yang mengalokasikan surplus mereka untuk investasi untuk mencapai tujuan sosial daripada memaksimalkan keuntungan bagi pemegang saham (Battarai, Kwong, \& Tasavori, 2019). Kajian tentang model kewirausahaan di Indonesia bisa dilihat dari misi sosial, aktivitas ekonomi, serta tata kelola yang bersifat partisipatif (Pratono, Pramudija, \& Sutanti, 2016).

\section{Misi Sosial}

Teori altruistik menjelaskan bagaimana perusahaan perlu membangun kredibilitas perusahaan dan dukungan masyarakat (Pratono \& Tjahjono, 2017). Oleh karena itu, penting untuk mengevaluasi sejauh mana kebijakan perusahaan mampu diwujudkan dalam bentuk kinerja keuangan maupun sosial (Bruton, Khavul, Siegel, \& Wright, 2015). Informasi sosial memainkan peran penting karena dukungan para pemangku kepentingan sangat menentukan bagi perusahaan dalam 
membuat keputusan (Kuppuswamy \& Bayus, 2018).

Inisiatif inovasi sosial melalui publikasi pernyataan misi mereka sangat penting untuk tujuan legitimasi dan akuntabilitas karena para pemangku kepentingan harus menyaring, memantau, dan mengevaluasi (Mersland, Nyarko, \& Szafarz, 2019). Masyarakat akan menikmati manfaat yang muncul dari inovasi sosial, tetapi ada kurangnya insentif ekonomi menimbulkan kegagalan pasar (Pol \& Ville, 2009). Kurangnya layanan pendidikan dasar dan perawatan kesehatan masih menjadi masalah umum bagi negara (Pratono, 2018). Oleh karena itu, lokus inovasi muncul dari pembelajaran kolektif menunjukkan interaksi antara berbagai aktor yang beroperasi dalam jaringan sosial yang sama dan perlu dikembangkan melalui pembelajaran bersama (Phillips, Lee, Ghobadian, O'Regan, \& James, 2015). Solusi pembentukan inovasi sosial menghasilkan nilainilai sosial-etika langsung untuk penerima manfaat, yang sebagian besar adalah orang-orang yang rentan dalam masyarakat (Lubberink, Blok, van Ophem, \& Omta, 2019).

\section{Inovasi sosial}

Konsep tentang inovasi sosial dan kewirausahaan sosial berkempang dari berbagai konsep dalam ilmu kompleksitas seperti fenomena berdirinya kewirausahaan sosial (Weathley \& Fieze, 2009), kemandirian organisasi (Tapsell \& Woods, 2010). Inovasi sosial dan kewirausahaan sosial memiliki keterkaitan konseptual yang kuat dengan kompleksitas ilmu. Beberapa artikel mencatat masalah sosial yang memotivasi inovator sosial dan pengusaha seringkali sangat kompleks
(Zivkovic, 2018). Yang lain berpendapat bahwa inovasi sosial dan kewirausahaan sosial sendiri harus dipahami sebagai proses yang kompleks, karena mereka sering melibatkan banyak aktor yang beroperasi dalam konteks yang dinamis dan muncul (Swanson \& Zhang, 2011).

Inovasi sosial adalah inisiatif untuk memenuhi kebutuhan masyarakat dengan menghasilkan produk, layanan, dan kegiatan baru, yang lebih efektif daripada pasar tradisional dan sektor publik (Moulaert, et al., 2013). Karena kegiatan crowdfunding dapat berpotensi mengganggu, kekhawatiran risiko crowdfunding dapat terjadi ketika satu atau lebih platform runtuh karena malpraktik (Ziegler, et al., 2018). Ada juga bahaya untuk crowdfunding dari beralih ke model investasi tradisional, yang bergantung pada bunga atau pengembalian ekuitas. Kurangnya peraturan untuk crowdfunding ekuitas memungkinkan tidak hanya akses online ke investor malaikat tetapi juga menawarkan sedikit perbedaan dengan keuangan mikro yang ada (Hornuf \& Schwienbacher, 2017). Skenario yang lebih buruk terjadi ketika penuntutan untuk penipuan jaminan sosial terkait dengan perilaku investasi yang tidak diatur, terutama oleh "kerumunan" konsumen-investor (Kuppuswamy \& Bayus, 2018).

\section{Metodologi Penelitian}

Penelitian ini digolongkan sebagai basic research karena bertujuan untuk mengembangkan teori kewirausahaan sosial. Desain penelitian yang digunakan dalam penelitian ini adalah studi kualitatif dengan jenis interpretatif-induktif. 
Ada tiga pendekatan dalam metodologi penelitian (Neuman, 2003. P. 70) yakni positivism, interpretive social science dan critical social science. Dalam penelitian ini peneliti menggunakan paradigm interpretive social science dengan pendekatan kualitatif. Ada 8 tipe variasi dari Interpretive social science yakni hermeneutik, konstruksionisme, etnomethodology, fenomenologi, kognitif, idealis, kualitatif sosiologi, subyektifisme. Tipe variasi yang digunakan peneliti yakni fenomenologis, yang menekankan pada peristiwa mental yang dialami seseorang atau fenomena mental yang dialami seseorang memang subyektif dan subyektivitas dalam penelitian fenomenologis bisa ditanggapi dengan mengatakan bahwa "fakta yang paling objektif tentang manusia yaitu manusia pada dasarnya subyektif (Kahija, 2017. P. 22). Maka penelitian fenomenologis merupakan kajian tentang fenomena (peristiwa, kejadian atau aktivitas mental) dalam berbagai macam pengalaman hidup seseorang.

Ada 2 jenis pendekatan fenomenologis yaitu fenomenologis interpretatif dan fenomenologis deskriptif. Fenomenologis interpretatif dalam penelitian ini peneliti ingin menginterpretasikan atau menafsirkan bagaimana partisipan memberi arti untuk pengalamannya, maka inti interpretasi itu merupakan laporan tentang pengalaman unik para partisipan dan bagaimana keunikan tersebut terhubung). Sedangkan fenomenologis deskriptif (peneliti ingin mendeskripsikan atau menggambarkan bagaimana setiap partisipan memberi arti untuk pengalamannya, maka inti dari deskripsi yaitu paham apa esensi atau inti dari seluruh pengalaman partisipan). Sehingga peneliti menggunakan fenomenologis interpretatif. Pada Penelitian interpretive biasanya bertujuan untuk memperoleh gambaran atau deskripsi terhadap suatu fenomena sosial yang ada dalam masyarakat melalui observasi secara mendetail agar dapat memperoleh pemahaman dan mengintepretasikan bagaimana pelaku di dalam dunia sosialnya.

\section{Profil responden}

Metode pengambilan data yang digunakan adalah dengan wawancara, penelitian kepustakaan dan dilengkapi juga dengan analisis dokumen dari narasumber untuk memperkuat dan menambah pemahaman peneliti. Wawancara dilakukan agar peneliti mengajukan pertanyaan yang tepat dan mengajak para partisipan untuk mendiskusikan makna dari pengalaman mereka yang memerlukan kesabaran dan keterampilan mereka sendiri (Creswell, 2015, p. 240).

Peneliti melakukan wawancara terbatas hanya kepada pendiri perusahaan yakni direktur atau manajer (pada Javara: Ibu Helianti Hilman, Ibu Sutji Sosrowardojo selaku kepala marketing communication dan RMC: Ferdinandus Watu serta adik sepupu pendiri yakni Eka Kopo yang merupakan Sekretaris dan juga penggerak pada RMC), wawancara pada penelitian ini menggunakan metode semi terstruktur dan jawaban dari partisipan selama proses wawancara langsung dilakukan pencatatan dan perekaman untuk memudahkan pendokumentasian dan diperoleh hasil yang verbatim, selain itu juga memudahkan peneliti lebih fokus pada responden (Rubin dan 
Babbie, 2008, p. 450).

Tabel 1. Profil respondent dan jenis wawancara

\begin{tabular}{|c|c|c|c|c|}
\hline $\begin{array}{c}\text { Respon } \\
\text { dent }\end{array}$ & Nama & $\begin{array}{c}\text { Jenis } \\
\text { Kela } \\
\text { min }\end{array}$ & Jabatan & $\begin{array}{c}\text { Jenis } \\
\text { Wawan } \\
\text { cara }\end{array}$ \\
\hline $\begin{array}{c}\text { Respond } \\
\text { ent 1 }\end{array}$ & $\begin{array}{c}\text { Helianti } \\
\text { Hilman }\end{array}$ & $\begin{array}{c}\text { Perem } \\
\text { puan }\end{array}$ & $\begin{array}{c}\text { Direktur } \\
\text { Javara }\end{array}$ & $\begin{array}{c}\text { Semi } \\
\text { Terstru } \\
\text { ktur }\end{array}$ \\
\hline $\begin{array}{c}\text { Respond } \\
\text { ent 2 }\end{array}$ & $\begin{array}{c}\text { Sosroward } \\
\text { ojo }\end{array}$ & $\begin{array}{c}\text { Perem } \\
\text { puan }\end{array}$ & $\begin{array}{c}\text { Kepala } \\
\text { commurketing } \\
\text { ation }\end{array}$ & $\begin{array}{c}\text { Semi } \\
\text { Terstru } \\
\text { ktur }\end{array}$ \\
\hline $\begin{array}{c}\text { Respond } \\
\text { ent 3 }\end{array}$ & $\begin{array}{c}\text { Ferdinand } \\
\text { us Watu }\end{array}$ & $\begin{array}{c}\text { Laki- } \\
\text { laki }\end{array}$ & $\begin{array}{c}\text { Direktur } \\
\text { RMC }\end{array}$ & $\begin{array}{c}\text { Semi } \\
\text { Terstru } \\
\text { ktur }\end{array}$ \\
\hline $\begin{array}{c}\text { Respond } \\
\text { ent 4 }\end{array}$ & Eka Kopo & $\begin{array}{c}\text { Laki- } \\
\text { laki }\end{array}$ & $\begin{array}{c}\text { Sekretaris } \\
\text { RMC }\end{array}$ & $\begin{array}{c}\text { Semi } \\
\text { Terstru } \\
\text { ktur }\end{array}$ \\
\hline
\end{tabular}

\section{Analisis Data}

Metode analisis data yang akan digunakan dalam penelitian ini adalah dengan kualitatif intepretatif secara induktif dari fenomena yang diteliti dengan menggunakan seperangkat prosedur yang sistematis, dengan menggunakan pendekatan fenomenologis, dimana fenomenologis sebagaimana yang dipahami merupakan salah satu jenis pendekatan yang didominasi oleh pembahasan akan fenomenafenomena. Sementara sisi ilmiah dari fenomenologis dapat dilihat dari penjelasannya yang membahas tentang pengalaman-pengalaman dalam bentuk-bentuknya (Denzin \& S. Lincoln, 2009).

Dan untuk menetapkan penelitian kualitatif sangat dibutuhkan evaluasi tentang keabsahan (trustworthiness) data dan juga teknik pemeriksaan agar data tersebut data dipercaya (Moleong, 2012, p. 324). Maka dari itu untuk menentukan keabsahan data dalam penelitian ini terdapat empat kriteria (Polit, Beck \& Hungler, 2001; Moleong, 2010) yaitu:

Hasil dari penelitian kualitatif dapat dipercaya pada saat mampu menampilkan pengalaman partisipan secara akurat (Speziale \& Carpenter, 2003). Maka dari itu peneliti menggunakan metode triangulasi untuk meminimalkan bias dalam penelitian ini, agar tidak terjadi bias kependapat individu semata.

\section{Hasil Temuan}

\section{Profil perusahaan}

\section{PT. Kampung Kearifan Indonesia (Javara Indigenious)}

Helianti Hilman mantap membangun PT. Kampung Kearifan lndonesia (Javara Indigenious) sejak November tahun 2008 yang berlokasi di Graha BS Lantai Dasar Jalan Kemang Utara A No. 3 Mampang Prapatan Kota Administrasi Jakarta Selatan, DKI Jakarta. Sejak pertama kali didirikan fokus PT. Kampung Kearifan lndonesia (Javara Indigenious) bukan sekadar berbisnis saja tapi juga ingin mempopulerkan hasil bumi Indonesia dari berbagai provinsi ke pasar global yang dikenal dengan nama brand "Javara". Arti dari nama Javara berasal dari bahasa Sansekerta yang berarti juara karena menggambarkan kekayaan hasil bumi terbaik dari pulau Jawa khususnya dan Indonesia umumnya. Serta untuk menunjukkan bahwa produk lokal Indonesia yang berbeda-beda dari daerah-daerah yang mempunyai local champion product bisa bersaing dengan produk kompetitor luar lainnya. Tujuan berdirinya usaha ini adalah untuk melestarikan keragaman hayati Indonesia dan memberdayakan petani untuk kembali membudidayakan varietas-varietas tanaman yang sudah hampir punah secara organik serta memfasilitasi pemasarannya. Pada mulanya produk- 
produk Javara dipasarkan melalui tokonya sendiri yang bernama "The Ethno Gourmet Shop" untuk menjangkau konsumennya. Dari toko kecil tersebut Javara terus berinovasi sehingga menjadi perusahaan perseroan terbatas yang dikenal dengan PT. Kampung Kearifan lndonesia (Javara Indigenious).

sebagian besar produk Javara lahir karena ada banyak masalah pada petani Indonesia seperti harga jatuh dan bencana alam yang harus memaksa mereka memanen hasil komoditasnya secara segera itulah yang memotivasi kita dalam mengembangkan produk jadi memang produk kami di drive sebagai bagian untuk mengatasi masalah sosial yang dialami petani Indonesia.

\section{Remaja Mandiri Community (RMC)}

Remaja Mandiri Community (RMC) Detusoko didirikan oleh Ferdinandus Watu di Desa Detusoko Barat, Kecamatan Detusoko, Kabupaten Ende Propinsi Nusa Tenggara Timur pada 17 Juli 2014. Beliau merupakan putra asli daerah Detusoko yang pernah mengecap pendidikan di Miami, Florida, Amerika Serikat. Oleh karena itu dalam kurun waktu 3 tahun terakhir, sebagai bagian dari insan penjaga kampung dan laskar pembangun desa, beliau menerapkan visi "ayo pulang kampung" dan ada berbagai kegiatan yang telah beliau kerjakan bersama teman-teman yakni kegiatan sosial yang berkaitan dengan pemberdayaan kawula muda, pengembangan ekonomi dan ekowisata dengan lokus aksi dari desa.

RMC sendiri adalah sebuah komunitas yang terdiri atas remaja anak-anak petani yang diarahkan untuk lebih mencintai profesi petani dan kembali ke kampung dalam arti membangun dari kampung. RMC didirikan karena Ferdinandus Watu merasa prihatin karena melihat sumber daya alam Detusoko yang berlimpah, produk-produk pertanian yang cukup banyak dan berkualitas baik hortikultura maupun tanaman komoditas, namun sumber daya manusia untuk mengelolanya kurang karena banyak kawula muda yang justru lebih senang ke kota dan lebih membanggakan kerja sebagai seorang pegawai negeri sipil atau bekerja dikantor dibandingkan bekerja sebagai petani dan mengembangkan daerahnya.

$\begin{array}{ccc}\text { Hasil temuan dari kedua } & \text { dans } \\ \text { perusahaan } & \text { tersebut mengadopsi }\end{array}$ model bisnis kewirausahaan sosial dengan cara sebagai berikut:

\section{Tujuan sosial muncul dari hasil interaksi dengan kelompok sasaran}

Dalam penelitian ini hasil dari pertanyaan penelitian yang pertama bagaimana kewirausahaan sosial menentukan tujuan organisasi pertama adalah jika ditilik dari pandangan sudut pandang kewirausahaan sosial melalui pengalaman berinteraksi dan observasi langsung para founder-nya bersama petani. Hal tersebut bisa dilihat dari interaksi founder Javara, Helianti Hilman bersama Kang Tarman dan Mbah Suko. Berdasarkan hasil interaksi tersebut, founder organisasi memutuskan bahwa tujuan organisasi yang dibentuknya nanti adalah untuk membantu para petani dan memberikan perubahan sosial pada para petani dan mempromosikan fair trade dalam rantai bisnis dengan 
membangun relasi sosial antara produsen dan konsumen yang membawa manfaat bagi masyarakat.

Javara telah mendasarkan pengabdiannya pada komitmen untuk mengembangkan sumber pangan lokal dari kepunahan sekaligus melindungi profesi petani yang mengembangkan jenis pangan lokal tersebut agar mereka memiliki martabat dari profesi petani yang mereka tekuni. Javara memberikan alternatif lain yang membuka jalan baru bagi para petani, setelah kaum ini begitu lama terkunkung di bawah jerat birokrasi yang ruwet dan sistem penjualan yang cenderung merugikan mereka. Dengan jalan ini Javara memberikan peluang yang besar bagi petani untuk melakukan inovasi bagi kebaikan mereka sendiri, baik dari segi kualitas produk, kuantitas produk dan profit.

Untuk kasus kedua, RMC, proses penentuan tujuan organisasi bersifat bottom up, di mana inisiator berasal dari masyarakat petani atau disebut putra daerah Fernando Watu. Founder lembaga ini sejak kecil telah mengalami sendiri betapa tertinggalnya daerah tempat lahir dan hidupnya. Hal ini dapat dibuktikan dengan kutipan di bawah ini: tumbuh di lingkungan yang identik dengan kemiskinan, keterbelakangan, dan label negatif soal pertanian membuat langkah Remaja Mandiri Community Detusoko jatuh bangun. Seperti yang diungkapkan secara langsung oleh sang pendiri Nando Watu mengenai:

\section{Pentingnya"....membangun kesadaran serta respek terhadap lingkungan dan budaya..." dengan semangat inilah Remaja Mandiri Community didirikan}

$$
\begin{array}{ccr}
\text { Untuk } & \text { pertanyaan } & \text { ini } \\
\text { jawabannya } & \text { adalah cara } & \text { RMC }
\end{array}
$$

mengembangkan produknya. Sekarang peneliti akan mengajak pembaca untuk melihat bagaimana RMC mengembangkan bidang pelayanannya. Sebagaimana dalam pengembangan bidang produk yang berawal dari gagasan sang pendiri, begitupun dalam sisi pengembangan layanan lagi-lagi berasal dari gagasan sang pendiri. Beliau dengan cerdik melihat melalui konsep ekowisata yang tak ayal lagi membutuhkan tidak hanya penyuguhan makanan organik dan alam yang indah tetapi juga menciptakan layanan one day be a farmer. Ini adalah jenis layanan dimana para pengunjung diberi kesempatan untuk melihat dari dekat proses pengolahan produk. Narasumber menjelaskan bahwa:

Melalui aktivitas ini terbangun interaksi aktif pengunjung dengan petani sehingga ada pertukaran informasi, pengetahuan dan pengalaman. Jenis pelayanan yang diberikan selalu berpatokan pada filosofi berpikir dengan otak, berkarya dengan hati. Yang dalam bahasa tradisional disebut dengan "Piki No'o Ote, Kema No'o Ate”. Maksud dari filosofi ini adalah semua layanan dari RMC haruslah merupakan kecerdasan berpikir atau dengan kata lain semua anggota RMC diwajibkan untuk memikirkan lebih dahulu dengan otak sebekum memberikan pelayanan tertentu. Adapun maksud dari Kema No'o Ate adalah semua pelayanan RMC haruslah keluar dari hati yang tulus dan tidak boleh disisipi dengan perasaan terpaksa atau tertekan. 
2. Mengandalkan bisnis murni dengan mengadopsi nilai-nilai yang berbasis pada kearifan lokal dan perdagangan yang adil

Studi ini menemukan banyak sekali kecocokan antara teori social enterprise dengan data penelitian tentang Javara. Jika dalam teori social enterprise dikatakan bahwa konsep yang diusung adalah menciptakan suatu inovasi baru yang mana fokusnya mengarah pada inovasi sosial bisnis tersebut bagi perkembangan masyarakat sekitar (Defourny \& Nyssens, 2017).

"......Enterprise has been
emerging as a new way to
describer entrepreneurial
organizational forms that focus
on social inovation and
society." (Ridley-Duff \&
Southcombe, 2012; Defourny and Nyssens, 2017) ..."

Selanjutnya hasil dari pertanyaan penelitian yang kedua, Bagaimana kewirausahaan sosial mengembangkan produk dan layanan yang inovatif dalam membantu masyarakat sekitarnya dengan mengadopsi nilai-nilai budaya dan kearifan lokal yaitu PT. Kampung Kearifan Indonesia (Javara Indigenious) menambahkan story behind the product dibalik proses produksinya dengan mengcreate winning product. Bagi Javara sebagai perusahaan ini adalah sebuah upaya pembeda dengan produk perusahaan lain dengan lebih menonjolkan sisi kearifan budaya Indonesia yang kental. Lebih lanjut cara Javara mengembangkan produk tidak terlepas dari pemahaman sang pendirinya Ibu Helianti Hilman mengatakan bahwa:
Untuk memasuki pasar mancanegara, prinsipnya sederhana yaitu create winning product (menciptakan produk yang unggul), harus ada pembeda, unik, jangan ikuti orang kebanyakan, kedua standardisasi produk. Hal ini berdampak pada penerimaan pasar global yang positif terhadap produk-produk Javara.

Taktik lain yang ditempuh Javara dalam pengembangan produknya adalah dengan memperluas cakupan bidang produknya dalam arti produkproduk tersebut tidak hanya monoton diambil dari produk hasil pertanian tapi juga hasil hutan, hasil laut, hasil dari lahan kering, gambut. Dengan cara ini Javara berusaha menjaga agar minat konsumennya tidak jenuh dan lesu akibat secara kontinu mengkonsumsi satu produk monoton yang sama. Untuk mengubah permasalahan yang dihadapi petani menjadi solusi terbaik yang positif bagi mereka, Javara selalu terbuka dan transparan dalam berbagai hal mulai dari kebutuhan, kapasitas jumlah yang dibutuhkan serta keuangan dan keuntungan yang didapat. Hal ini menanamkan rasa saling percaya antara kedua pihak, karena sedari dulu petani selalu sering dikecewakan dari banyak faktor dan masalah-masalah yang dialami mereka. Javara berusaha untuk terus bergandengan tangan bersama untuk menjaga sustainabilitas yang terjalin antara keduanya.

Pada tahap ini, peneliti menyimpulkan bahwa keberadaan Javara telah sesuai dengan isi ajaran dalam teori sociopreneur yang lebih menfokuskan pembahasannya akan 
dampak kehadiran sebuah bisnis terhadap masyarakat disekitarnya. Lebih lanjut Javara melakukan terobosan dengan prinsip good, clean dan quality maksudnya tiap produk yang dikeluarkan oleh Javara harus enak, sehat, diproduksi dengan teknologi yang berkualitas tinggi. Dapat dikatakan inilah salah satu keunikan Javara, mereka menekankan keseimbangan dalam sebuah produk mengingat banyak perusahaan yang hanya menekankan salah satu aspek dari ketiga unsur di atas. Contohnya memproduksi makanan yang sehat tapi tidak enak sehingga tidak laku, memproduksi makanan enak tapi tidak sehat sehingga memberikan dampak negatif bagi kesehatan konsumen, menghasilkan produk yang sehat dan enak tapi dengan teknologi yang murahan.

Disamping itu Javara juga perintis slow food di Indonesia yaitu sebuah tren yang mengedepankan makanan yang baik, sehat, adil sekaligus enak.

Seperti yang dikatakan beliau bahwa:

Permasalahan yang terjadi pada petani tiap hari mbak, karena dari dulu petani sudah pernah dikecewakan, namun intinya ada 2 kekuatan:

1. Integritas niat kita, karena kalau kita datang dengan itikad baik dan menjaga integritas hati, tidak hanya mencari keuntungan belaka namun membantu mereka menjawab solusi dan berjuang untuk menghilangkan kolonialisme karena kekuatan dari ketulusan mampu mengalahkan sesuatu yang berniat negatif ibaratnya susah dan senang mari bareng-bareng.
2. Bagaimana kita membangun branding sangat penting agar dikenal dan karena kita memulai dengan itikad yang baik, tulus dan confidence dimulai dari awal contoh garam Kusamba Bali ini awalnya kami uji coba kepada para chef karena mereka sangat peka dengan kualitas dan para chef mengira garam tersebut berasal dari Perancis. Mulai dari sini kami mulai mendapat kepercayaan dan orderan tentunya.

Bagi RMC, upaya mengembangkan sisi pelayanannya adalah membangun Lepa Lio Café. Lepa berasal dari bahasa setempat yang berarti pondok tempat para petani istirahat. Meskipun letak RMC jauh dari ibu kota kabupaten Lepa Lio Café tetap dibangun dengan sentuhan moderen sebagai tempat nongkrong kekinian. Lepa Lio Café yang berdiri sejak Oktober 2018 lalu, disediakan bagi para pengunjung sebagai tempat untuk menikmati aneka pangan lokal yang ditemani dengan sajian Kopi Detusoko. Menurut beliau menyatakan bahwa:

$\begin{array}{lr}\text { Ini adalah cara } & \text { RMC } \\ \text { mengembangkan } & \text { bidang } \\ \text { pelayanannya dalam } & \text { segmen } \\ \text { promosi dan pemasaran } & \text { secara langsung yang } \\ \text { bertujuan untuk } & \text { membuat } \\ \text { komoditas setempat } & \text { semakin } \\ \text { dikenal luas. } & \end{array}$

Lembaga ini berharap berharap langkah yang ditempuh menjadi bagian dari upaya untuk meningkatkan nilai ekonomi dari setiap komoditas pertanian dan perkebunan. Sejauh ini beliau 
mengamati bahwa hasil alam Flores dijual dalam bentuk mentah, bukan berupa produk turunan atau olahan dengan nilai yang lebih tinggi. Apa yang dilakukan RMC dalam usahanya dalam bidang pelayanan tidak hanya ditujukkan untuk skala kecil dalam arti hanya untuk menginspirasi anggota RMC semata, tetapi skala besarnya yaitu menginspirasi kaum muda di daerah NTT dan sekitarnya.

Sudah saatnya kaum muda bergerak mulai dari desa dan membangun dari kampung halamannya sendiri. Lebih lanjut beliau mengatakan bahwa:

\section{Petani adalah masa depan dan Flores ini adalah tanah yang menghasilkan. Karena itu harus banyak orang muda mencintai pertanian dan kembali kekampung.}

Yang kedua adalah dengan cara memberikan layanan sebagai inkubator farmpreneur kepada kawula muda melalui Sekolah Seniman Pangan Flores dengan dukungan dari jaringan lokal maupun Internasional. Berikutnya ditemukan bahwa cara mengembangkan layanan RMC adalah menciptakan program one day be a farmer, mengadakan acara Gare Bego, mendirikan Lepa Lio Café, menjalankan filosofi Piki No'o Ote, Kema No'o Ate, menjalin kolaborasi dengan organisasi nasional dan internasional.

\section{Melibatkan para pemangku kepentingan dalam tata kelola jalur produksi dan distribusi}

Javara juga adalah perusahaan pertama yang menerapkan konsep farmpreneur yaitu sebuah konsep yang menjadikan petani pengelola lahannya sekaligus pembisnis hasil pertaniannya. Konsep ini adalah yang pertama di Indonesia. Dan inilah keunikan kedua dari Javara. Berikutnya Javara membawa para petani keluar negeri untuk berinteraksi langsung dengan konsumen pengguna dari produk yang mereka hasilkan. Hal ini memberikan kebanggaan bagi para petani dan merupakan keunikan ketiga dari Javara karena sebelumnya belum ada perusahaan Indonesia yang memiliki konsep seperti ini. Javara juga merupakan perusahaan yang pertama kali memasarkan produk-produk Indonesia yang hampir punah seperti Cempo Merah, Wangi Menyan, Andal Abang dan Methik Susu.

Untuk mengubah permasalahan yang dihadapi petani menjadi solusi terbaik yang positif bagi mereka, kami selalu terbuka dan transparan dalam berbagai hal mulai dari kebutuhan, kapasitas jumlah yang dibutuhkan serta keuangan dan keuntungan yang didapat. Hal ini menanamkan rasa saling percaya antara kedua pihak, karena sedari dulu petani selalu sering dikecewakan dari banyak faktor dan masalahmasalah yang dialami mereka. Javara berusaha untuk terus bergandengan tangan bersama untuk menjaga sustainabilitas yang terjalin antara keduanya. Seperti yang dikatakan beliau bahwa:

Permasalahan yang terjadi pada petani tiap hari mbak, karena dari dulu petani sudah pernah dikecewakan, namun intinya ada 2 kekuatan:

1. Integritas niat kita, karena kalau kita datang dengan itikad baik dan menjaga integritas hati, tidak hanya mencari keuntungan belaka 
namun membantu mereka menjawab solusi dan berjuang untuk menghilangkan kolonialisme karena kekuatan dari ketulusan mampu mengalahkan sesuatu yang berniat negatif ibaratnya susah dan senang mari bareng-bareng.

2. Bagaimana kita membangun branding sangat penting agar dikenal dan karena kita memulai dengan itikad yang baik, tulus dan confidence dimulai dari awal contoh garam Kusamba Bali ini awalnya kami uji coba kepada para chef karena mereka sangat peka dengan kualitas dan para chef mengira garam tersebut berasal dari Perancis. Mulai dari sini kami mulai mendapat kepercayaan dan orderan tentunya.

Untuk pertanyaan nomor tiga yakni bagaimana tata kelola kewirausahaan Javara dalam menentukan distribusi keuntungan yang adil?. Jawabannya terletak pada penerapan sistem fair trade pada Javara. Hal ini disebabkan karena sejak semula sistem perdagangan yang adil (fair trade) menjadi fondasi terbentuknya PT. Kampung Kearifan Indonesia (Javara Indigenious) dalam menjaga keutuhan dan relasi, tidak hanya pada mitra namun terhadap sang pencipta, alam dan manusia sebagai konsumen. Inti dari dukungan yang diberikan terbagi menjadi dua macam yaitu dukungan secara finansial dan dukungan secara jaringan baik secara Lokal, Nasional dan Internasional yang mendukung Javara untuk terus berkarya serta mempertahankan eksistensisnya di zaman, dimana semua orang tidak terlalu menghargai biodiversitas pangan Indonesia karena adanya pengaruh fast food yang berakibat buruk pada kesehatan konsumen makanan tersebut.

Bagaimana tata kelola kewirausahaan dalam menentukan distribusi keuntungan yang adil?. Sama halnya dengan javara, RMC juga bergerak dengan sumber finansial yang mandiri. Dalam arti menggunakan modal sendiri. Penggunaan modal ini bertujuan untuk menciptakan etos kemandirian dikalangan internal RMC maupun pihak-pihak eksternal yaitu orangorang muda yang diberdayakan oleh RMC. Sehingga RMC dapat berdiri kokoh dan tidak diperalat oleh pihakpihak luar yang berusaha memonopoli dengan cara yang illegal dan melalui samaran pemberian bantuan dana. Menurut Nando Watu bahwa:

Sumber finansial yang menjadi modal RMC berupa penggunaan modal pribadi. Modal pribadi ini biasanya berasal dari iuran anggota, bantuan/sumbangan hibah yang bersifat sukarela dan tidak mengikat.

Ini adalah sumber finansial awal ketika RMC masih bergerak sebagai sebuah bayi organisasi. Dalam ideologinya memang gambaran sebagai sebuah perusahaan yang mandiri yang lepas dari campur tangan bahkan monopoli pihak lain adalah ide yang sudah sejak awal tergurat dalam kepala Nando Watu sebelum mendirikan RMC.

Kendatipun demikian RMC tentu saja tidak menutup mata pada perkembangan yang terjadi dalam pangsa kompetisi perdagangan barang dan jasa. Bahwasannya semakin hari 
persaingan dibidang ini semakin meningkat dan rumit. Oleh karena itu RMC menggunakan bantuan dana dari pihak luar yakni dengan pinjaman. Hal ini terlihat pada pernyataan beliau bahwa:

Guna memperbesar RMC, kami bisa memperoleh pinjaman yang tidak merugikan kelompok dan pinjaman ini kami dapat dari anggota, koperasi, sumber keuangan yang sah dan bank atau lembaga keuangan lainnya.

Dua saluran sokongan finansial inilah yang selama ini telah ditempuh RMC. Sebagai upaya untuk menjamin proses produksi, distribusi dan komersialisasi produk-produknya. Secara jelas ditampilkan bahwa gambaran besar dari sumber finansial RMC berdasarkan pada poros inovasi dan poros kooperatif. Perwujudnyataan dari poros inovasi adalah melalui modal-modal usaha RMC sendiri karena untuk menghasilkan modal mandiri diperlukan inovasi yang independen juga. Sedangkan aktualisasi dari poros kooperatif dapat dilihat dari aktivitas meminjam dana dari pihak luar. Yang mana kegiatan ini harus melibatkan kerjasama antar pihak peminjam dan pemberi.

\section{Diskusi}

Peneliti melihat bahwa pembahasan diskusi dalam penelitian ini meliputi:

a. Kontribusi teori:

- Teori kewirausahaan sosial bisa diterapkan baik diskala lokal maupun nasional dengan kemungkinan keuntungan yang sama.
- Titik pijak teori kewirausahaan sosial selalu sama yaitu niat untuk membantu masyarakat dan penerapannya dilapangan.

- Teori kewirausahaan sosial merupakan teori yang tidak dapat berdiri sendiri. Teori ini harus dibantu dengan teori-teori lainnya seperti teori fenomenologis dan spiritual manajemen.

b. Praktek manajemen:

- Penerapan manajemen bisnis Javara maupun RMC sama-sama berfokus pada pengaturan usaha agar sesuai dengan kebutuhan masyarakat yang akan dibantu khususnya petani dan anak muda.

- Obyek sasaran yang diatur oleh PT. Kampung Kearifan Indonesia (Javara Indigenious) maupun Remaja Mandiri Community (RMC) samasama merupakan obyek yang vital tapi sering diabaikan.

- Gaya manajemen terapan PT. Kampung Kearifan Indonesia (Javara Indigenious) maupun Remaja Mandiri Community (RMC) adalah gaya partisipan maksudnya obyek sasaran yang mau dibantu dilibatkan dalam proses pencarian solusi masalah mereka. 


\section{Kesimpulan}

Peneliti mengambil benang merah secara keseluruhan dari hasil interpretasi dan analisis peneliti mulai dari bab sebelumnya, maka kesimpulan yang didapatkan sepanjang penelitian ini adalah:

A. Jawaban untuk pertanyaan pertama adalah bagaimana kewirausahaan sosial menentukan tujuan organisasi yakni:

1. Tujuan sosial muncul dari hasil interaksi dengan kelompok sasaran:

a. PT. Kampung Kearifan Indonesia (Javara Indigenious) yakni, khusus untuk pengalaman berinteraksi dan observasi langsung para founder-nya bersama petani. Berdasarkan hasil interaksi tersebut, founder organisasi memutuskan bahwa tujuan organisasi yang dibentuknya nanti adalah untuk membantu para petani dan memberikan perubahan sosial pada para petani dan mempromosikan fair trade dalam rantai bisnis dengan membangun relasi sosial antara produsen dan konsumen yang membawa manfaat bagi masyarakat serta Javara telah mendasarkan pengabdiannya pada komitmen untuk mengembangkan sumber pangan lokal dari kepunahan sekaligus melindungi profesi petani yang mengembangkan jenis pangan lokal tersebut agar mereka memiliki martabat dari profesi petani yang mereka tekuni. Javara memberikan peluang yang besar bagi petani untuk melakukan inovasi bagi kebaikan mereka sendiri, baik dari segi kualitas produk, kuantitas produk dan profit.

b. Remaja Mandiri Community (RMC) yakni, proses penentuan tujuan organisasi bersifat bottom up, di mana inisiator berasal dari masyarakat petani atau disebut putra daerah Fernando Watu. RMC mengembangkan produknya dan mengembangkan bidang pelayanan. Sebagaimana dalam pengembangan bidang produk yang berawal dari gagasan sang pendiri, begitupun dalam sisi pengembangan layanan lagilagi berasal dari gagasan sang pendiri. Beliau dengan cerdik melihat melalui konsep ekowisata yang tak ayal lagi membutuhkan tidak hanya penyuguhan makanan organik dan alam yang indah tetapi juga menciptakan layanan one day be a farmer (jenis layanan dimana para pengunjung diberi kesempatan untuk melihat dari dekat proses pengolahan produk)

B. Jawaban untuk pertanyaan kedua bagaimana kewirausahaan sosial mengembangkan produk dan layanan yang inovatif dalam membantu masyarakat sekitarnya dengan mengadopsi nilai-nilai budaya dan kearifan lokal yakni:

1. Mengandalkan bisnis murni denganmengadopsi nilai-nilai yang berbasis pada kearifan lokal dan perdagangan yang adil serta melibatkan para pemangku kepentingan dalam tata kelola 
jalur produksi dan distribusi yakni:

a. PT. Kampung Kearifan Indonesia (Javara Indigenious) dengan cara menambahkan story behind the product dibalik proses produksinya dengan mengcreate winning product. Bagi Javara sebagai perusahaan ini adalah sebuah upaya pembeda dengan produk perusahaan lain dengan lebih menonjolkan sisi kearifan budaya Indonesia yang kental, memperluas cakupan bidang produknya dalam arti produk-produk tersebut tidak hanya monoton diambil dari produk hasil pertanian tapi juga hasil hutan, hasil laut, hasil dari lahan kering, gambut , Javara juga melakukan terobosan dengan prinsip good, clean dan quality maksudnya tiap produk yang dikeluarkan oleh Javara harus enak, sehat, diproduksi dengan teknologi yang berkualitas tinggi sertaperusahaan perintis slow food di Indonesia.

b. Remaja Mandiri Community (RMC) yakni, upaya mengembangkan sisi pelayanannya adalah membangun Lepa Lio Café untuk meningkatkan nilai ekonomi dari setiap komoditas pertanian dan perkebunan serta memberikan layanan sebagai inkubator farmpreneur kepada kawula muda melalui Sekolah Seniman
Pangan Flores dengan dukungan dari jaringan lokal maupun Internasional.

C. Jawaban untuk pertanyaan ketiga bagaimana tata kelola kewirausahaan Javara dalam menentukan distribusi keuntungan yang adil yakni:

1. Melibatkan para pemangku kepentingan dalam tata kelola jalur produksi dan distribusi yakni:

a. PT. Kampung Kearifan Indonesia (Javara Indigenious) dengan cara penerapan sistem fair trade yang menjadi fondasi terbentuknya perusahaan dalam menjaga keutuhan dan relasi, tidak hanya pada mitra namun terhadap sang pencipta, alam dan manusia sebagai konsumen. Serta inti dari dukungan yang diberikan terbagi menjadi dua macam yaitu dukungan secara finansial dan dukungan secara jaringan baik secara Lokal, Nasional dan Internasional yang mendukung Javara untuk terus berkarya serta mempertahankan

eksistensisnya di zaman, dimana semua orang tidak terlalu menghargai biodiversitas pangan Indonesia karena adanya pengaruh fast food yang berakibat buruk pada kesehatan konsumen makanan tersebut.

b. Remaja Mandiri

Community (RMC) yakni, sama halnya dengan Javara, RMC juga bergerak dengan sumber finansial yang 
mandiri dengan modal sendiri yang bertujuan untuk menciptakan etos kemandirian dikalangan internal RMC maupun pihak-pihak eksternal yaitu orang-orang muda yang diberdayakan oleh RMC. RMC juga menggunakan bantuan dana dari pihak luar yakni dengan pinjaman. Dua saluran sokongan finansial inilah yang selama ini telah ditempuh RMC sebagai upaya untuk menjamin proses produksi, distribusi dan komersialisasi produkproduknya. Secara jelas ditampilkan bahwa gambaran besar dari sumber finansial RMC berdasarkan pada poros inovasi dan poros kooperatif.

D. PT. Kampung Kearifan Indonesia (Javara Indigenious) merupakan perusahaan Indonesia pertama yang sangat fokus untuk membantu petani dan menjaga kearifan pangan Indonesia yang hampir punah.

E. Sementara halnya dengan Remaja Mandiri Community (RMC) merupakan komunitas lokal pertama khususnya di wilayah Flores, yang memulai usaha untuk memberdayakan para petani, khususnya kawula muda secara intensif untuk kembali ke desa dan membangun pertanian, pariwisata serta menjaga warisan pangan lokal yang hampir punah.

F. Social Enterpreneur berkaitan dengan pelaku wirausaha secara individu sedangkan Social Enterprise membahas aspek kolektivitas perusahaan dalam menyelesaikan masalah yang dihadapi.

G. PT. Kampung Kearifan Indonesia (Javara Indigenious) maupun Remaja Mandiri Community (RMC) berbeda dari sasaran pengembangan. PT. Kampung Kearifan Indonesia (Javara Indigenious) membidik petani dari segala usia, sedangkan Remaja Mandiri Community (RMC) fokus kepada anak muda dan para petani muda.

\section{Daftar Pustaka}

A Journey Bespoke. 7 April 2017. Meet Ibu Helianti Hilman of artisanal food Company Javara Indigenous Indonesia. http://ajourneybespoke.com/peop le/ibu-helianti-hilman-javaraindigenous-indonesia/. Diakses pada 28 Oktober 2019, pukul $10.00 \mathrm{pm}$.

Ajani, Dita 2013, 'Javara: Treasuring food biodiversity', The Jakarta Post 26 May. Available from:(http://www.thejakartapost. com/news/2013/05/26/javaratreasuring-foodbiodiversity.html). [30April 2015]. Diakses pada 28 Oktober 2019, pukul $10.00 \mathrm{pm}$.

Anderson, L., \& Thorpe, R. (2004). New perspectives on action learning: Developing criticality. Journal of European Industrial Training, 28(8/9), 657-668.

Battarai, C. B., Kwong, C. C., \& Tasavori, M. (2019). Market orientation, market disruptiveness capability and social enterprise performance: An empirical study from the United Kingdom. Journal of Business Research, 96, 47-60.

Bidet, E., \& Defourny, J. (2019). Social Enterprise in Asia: 
Theory, Models and Practice. New York and London: Routledge.

Borzaga, C., \& Defourny, J. (2004). The Emergence of Social Enterprise. London and New York: Routledge.

Bruton, G., Khavul, S., Siegel, D., \& Wright, M. (2015). New financial alternatives in seeding entrepreneurship: Microfinance, crowdfunding, and peer-to-peer innovations. Entrepreneurship Theory and Practice, 39(1), 9-26.

Cardon, M. S., Wincent, J., Singh, J., \& Drnovsek, M. (2009). The nature and experience of entrepreneurial passion. Academy of Management Review, 34(3), 511-532.

Clarke, J. (2011). Revitalizing Entrepreneurship: How Visual Symbols are Used in Entrepreneurial Performances. Journal of Management Studies, 48(6), 1365-1391.

Defourny, J., \& Nyssens, M. (2017). Mapping social enterprise models: Some evidence from the ICSEM project. Social Enterpise Journal, 13(4), 318-328.

Dewanti, Ayu P., Kenia Agha \& Dicky Zulkarnain. 2014. 'Javara'. Esquire Indonesia, 85.

Jones, O., \& Holt, R. (2008). The creation and evolution of new business ventures: an activity theory perspective. Journal of Small Business and Enterprise Development, 15(1), 51-73.

Karatas-Ozkan, M (2011). Understanding relational qualities of entrepreneurial learning: towards a multi-layered approach. Entrepreneurship \& Regional Development, 23, 877906.
Kelly, D., Steiner, A., Mazzei, M., \& Baker, R. (2019). Filling a void? The role of social enterprise in addressing social isolation and loneliness in rural communities. Journal of Rural Studies, https://doi.org/10.1016/j.jrurstud. 2019.01.024.

Kuppuswamy, V., \& Bayus, B. L. (2018). Crowdfunding Creative Ideas: The Dynamics of Project Backers. In D. Cumming, \& L. Hornuf (Eds.), The Economics of Crowdfunding (pp. 151-182). Basingstoke: Palgrave Macmillan.

Langley, P., \& Leyshon, A. (2017). Capitalizing on the crowd: The monetary and financial ecologies of crowdfunding. Environment and Planning, 49(5), 1019-1039.

Lubberink, R., Blok, V., van Ophem, J., \& Omta, O. (2019). Responsible innovation by social entrepreneurs: an exploratory study of values integration in innovations. Journal of Responsible Innovation, 6(2), 179-210.

McElroy, M. W. (2002). Social innovation capital. Journal of Intellectual Capital, 3(1), 30-39.

Mersland, R., Nyarko, S. A., \& Szafarz, A. (2019). Do social enterprises walk the talk? Assessing microfinance performances with mission statements. Journal of Business Venturing Insights, https://doi.org/10.1016/j.jbvi.201 9.e00117.

Phillips, W., Lee, H., Ghobadian, A., O'Regan, N., \& James, P. (2015). Social innovation and social entrepreneurship: A systematic review. Group \& Organization Management, 40(30), 428-461. 
Pol, E., \& Ville, S. (2009). Social innovation: Buzz word or enduring term? The Journal of Socio-Economics, 38(6), 878885.

Pratono, A. H., \& Maharani, A. (2018). Long-term care in Indonesia: The role of integrated service post for elderly. Journal of Aging and Health, 30(10), 1556-1573.

Pratono, A. H., \& Tjahjono, G. (2017). How does materialistic attitude influence the impact of corporate brand on the customers' intention to donate to corporates' charity? Humanomics, 33(4), 484-498.

Pratono, A. H., Pramudija, P., \& Sutanti, A. (2016). Social enterprise in Indonesia: Emerging models under transition government. ICSEM Working Paper No 36, Liege: The International Comparative Social Enterprise Model (ICESM) Project

Stinchfield, B. T., Nelson, R. E., \& Wood, M. S. (2012). Learning from Levi-Strauss' Legacy: Art, Craft, Engineering, Bricolage, and Brokerage in Entrepreneurship.

Entrepreneurship Theory \& Practice, 37(4), 889-921.

Swanson, L. A., \& Zhang, D. (2011). Complexity theory and the social entrepreneurship

Emergence: Complexity \& Organization, 13(3), 39-56.

Tapsell, P., \& Woods, C. (2010). Social entrepreneurship and innovation: Self-organization in an indigenous context. Entrepreneurship \& Regional Development, 22(6), 535-556.

Wang, C. L., \& Chugh, H. (2014). Entrepreneurial learning: past research and future challenges. International Journal of Management Review, 16, 24-61.

Weathley, M., \& Fieze, D. (2009). Using emergence to take social innovations to scale. Sundance, Utah, USA: The Berkana Institute.

Wulandari, Andhina. 10 Desember 2018. Produk Organik Indonesia Jajaki Pasar Inggris. https://bali.bisnis.com/read/2018 1210/99/867812/javascript.

Diakses pada 29 Oktober 2019, pukul $11.20 \mathrm{pm}$.

Yunxia, Z. H., Rooney, D., \& Phillips, N. (2016). PracticeBased Wisdom Theory for Integrating Institutional Logics: A New Model for Social Entrepreneurship Learning and Education. Academy of Management Learning \& Education, 607-625.

Zivkovic, S. (2018). Systemic innovation labs: a lab for wicked problems. Social Enterprise Journal, 14(3), 348-366 